\title{
Semantics Equivalence of Cultural Terms of Meurukon Texts Translated from Acehnese into \\ Indonesian
}

\author{
Nurlaila, Syahron Lubis, Tengku Sylvana Sinar and \\ Muhizar Muchtar \\ Faculty of Cultural Studies, Department of Linguistics, University of Sumatera \\ Utara, Medan, Indonesia
}

\begin{abstract}
Purpose - This paper is aimed at describing semantics equivalence of cultural terms in meurukon texts translated from Acehnese into Indonesian. A qualitative descriptive approach is used to analyze the context of semantics equivalence in these texts: varied semantics structure, especially the ones caused by the cultural gap between the two languages.

Design/Methodology/Approach - This research is designed to be of qualitative descriptive nature, wherein data are documented and analyzed using various methods proposed by Miles, Huberman, and Saldana (2014), such as data condensation, data display, drawing and verifying conclusions. The researcher is considered the key instrument in the whole process. The source of the data collected is from meurukon texts and its translation that consists of 623 sentences: they mainly comprise words and phrases that contain semantics equivalence of cultural terms.

Findings - The result of the research shows that there are 129 cultural terms found in 623 sentences. Of the analyzed data, it is seen that only $16.66 \%$ of the data is not equivalent with the target text, while $83.34 \%$ words and phrases of meurukon text are equivalent. This suggests that as a result of translation, the meurukon text has high semantics or lexical equivalences with the target text.

Research Limitations/Implications - This research is focused on semantics equivalence found in meurukon texts. The semantic equivalence here only pertains to lexical meaning of nouns and adjectives by using componential analysis.

Practical Implications - The result can be used in a sample of ways for the analysis of semantics equivalence of cultural terms in meurukon text translated from Acehnese into Indonesian using componential analysis.
\end{abstract}

Originality/value - This research identifies meurukon as an oral tradition of Acehnese culture, which is in the question and answer format about Islamic law in Aceh, specifically North Aceh.

Keywords Meurukon, semantics equivalence, cultural terms

All papers within this proceedings volume have been peer reviewed by the scientific committee of the Malikussaleh International Conference on Multidisciplinary Studies (MICoMS 2017).

(C) Nurlaila, Syahron Lubis, Tengku Sylvana Sinar, Muhizar Muchtar. Published in the Emerald Reach Proceedings Series. Published by Emerald Publishing Limited. This article is published under the Creative Commons Attribution (CC BY 4.0) licence. Anyone may reproduce, distribute, translate and create derivative works of this article (for both commercial and non-commercial purposes), subject to full attribution to the original publication and authors. The full terms of this licence may be seen at http://creativecommons.org/licences/by/4.0/legalcode

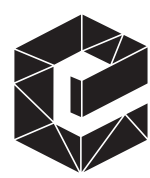

Emerald Reach Proceedings Series Vol. 1 Emerald Publishing Limited 2516-2853 DOI 10.1108/978-1-78756-793-1-00094 


\section{Proceedings of MICoMS 2017}

\section{4}

\section{Introduction}

Meurukon, a specific Acehnese culture that is almost extinct in the Acehnese society, is one culture that needs to be conserved to prevent it from being extinct among the people of Aceh in particular and Indonesia in general. This has been the motivating factor for the researcher to analyze the semantics equivalence of cultural terms found in the minority people of North Aceh maintained in meurukon texts, translated into Indonesian to be published in all the Aceh areas with a hope to make it familiar with all the people of Indonesia since Acehnese culture is also a part of Indonesia. The research in that direction is most vital because the translation should be able to reflect the meaning of original text in order to ensure that the originally intended meaning in source text has been transferred accurately into acceptable meaning in target text.

Translation theory is created not for any one specific language, but can also be applied to all the languages in the world and in all kinds of texts, due to significant cultural differences between one region and another. Thus it is a difficult task to translate cultural texts than any other types of texts. The focus of translation needs to be on some elements such as the differences in terms of linguistics and similarities in terms of culture itself. It can be said that being a translator of cultural texts is more challenging than being a translator of other kinds of texts. Nevertheless, translation of cultural text is considered to be more interesting and knowledgeably more meaningful, and would need a variety of translation strategies and techniques to achieve good results (Lubis, 2010).

To present the culture variation between one region and the other, there needs to be a specific language that may not be easily understood by the people in a different country or region. To minimize the complication, information needs to be used as a tool to introduce local culture. In fact, in Indonesia, most of the local culture was unable to be understood by other society since those texts are found only in the local language, hence creating a barrier in the process of understanding the culture by the people who live in other cities in the same country. One of the eforts that can be taken to make the local culture stay longer is by analyzing the product of translation on local culture into Indonesian. That would mean to ensure the Indonesian society understands the components of meaning contained in a translational work of local culture.

This article focuses mainly on meurukon, an activity of asking and answering a question about Islamic law in the form of poetry with good rhythm. Meurukon is a kind of oral tradition that has developed in Acehnese society, which contains great Islamic value that is in line with the Acehnese tradition. In this culture, "meurukon" seems to be a collaboration between rhythm and religion. The reason why this topic is chosen is based on a preliminary study which showed that while some meanings are equivalent some are not. See, for instance, the example provided below:

The translator has translated the word Syehkuna into "guru" (teacher) in target language. The word syehkuna is a specific cultural term and is an untranslatable word, because it has no equivalent terminology in the target language. When it is translated into word "guru" (teacher) in target language, the cultural significances contained in the word syehkuna is lost.

Table 1.

Example of Equivalence Problem Found in Meurukon Text

Source Text

Meu'a lon lake ubak Syehkuna (I ask forgiveness to Syehkuna)
Target Text

Maaf saya mohonkan pada guru (I ask forgiveness to teacher) 
This fact led us to conduct a scientific research to analyze the semantics structure in meurukon texts. This seems to be a way to prevent, preserve, and introduce the culture of meurukon to the younger generation so that the culture does not go extinct.

This article focuses only on semantics equivalence contained in the translation of meurukon texts. Using componential analysis, semantics equivalence is achieved only on lexical semantics of cultural terms that comprises nouns and adjectives.

Catford (1965) defined translation as the replacement of text material in one language (source language) by equivalent textual material in another language (target language). Further, Newmark (1988) defined translation as the rendering of the meaning of a text into another language in such a way that the author originally intended the text. Furthermore, Bell (1991) stated that "Translation is the expression in another language (target language) of what has been expressed in another, source language, preserving semantic and stylistics equivalence." Translation can be said as a process of transferring proper meaning of words, phrases, clauses, and sentences from one language into another or from source language into target language.

In transfering meaning from one language into another, we must pay attention on equivalences. Baker divided equivalence into four: (1) equivalence that can appear at word level and above the word level, when translating from one language into another; (2) grammatical equivalence, when referring to the diversity of grammatical categories across languages; (3) textual equivalence, when referring to the equivalence between an SL (Source Language, in this case, Acehnese) text and a TL (Target Language, Indonesian) text in terms of information and cohesion; and (4) pragmatic equivalence, when referring to implicatures and strategies of avoidance during the translation process (Baker, 2011).

Meurukon is a term which is closely related to Islam and it is derived from the word "rukun (pillar)." The activity of studying rukon is called meurukon in Acehnese. The activity in the form of religious art is the form of confession about the existence of Islam and to learn deeply from its principles. Those principles revolve around worship, the principles of aqiqah, the principles of shalat, the principles of slaughter, and furthermore is discussed deeply in the form of poem and art.

The art of meurukon brought about a positive effect in the creation of character, courtesy, behavior, and good character as a human being. Acehnese society is acclaimed to be known as the society of "serambi Mekkah," which believes that Islamic religion will bring happiness on the days here and after. Islamic religion should be developed and propagated to all aspects of life using some methods. Meurukon is one such method used as the missionary endeavor by the Acehnese in the past in delivering those principles of Islam.

According to Usman (2009), the function of meurukon is basically to intensify the Islamic teaching. In other words, the culture of meurukon is an educative Acehnese culture that contains educational elements in it. People find it more interesting to learn about religion through this art form since it is performed in the form of poem and not as the process of learning as is usually followed in a classroom teaching. In that sense, meurukon becomes a performance and entertaining art, in which the semantic equivalence is focused on cultural words as proposed by Newmark.

Newmark (1988) defines that "cultural word is words referring to objects, processes, institutions, custom, ideas peculiar to one group of people." From that definition, it can be understood that the term culture refers to specific culture and generally they are difficult to be translated and each community has their own culture, different beliefs, and different social organization. According to Newmark (1988), culture can be divided into five categories: (1) ecology - geographical and territory; (2) material culture - food, clothes, 
Proceedings of places, transportations; (3) social culture - leisure and work; (4) organization, customs, MICoMS 2017 ideas - artistic, political and social, and religious; and (5) gesture and habits.

\section{Methods}

The kind of research adapted in this study is qualitative descriptive that answers the problem of semantics equivalence in the meurukon texts qualitatively, especially on the differences between semantics structure/meaning that was caused by the cultural gap between two cultures, Aceh and Indonesia. The data for this research was taken from the document of meurukon text and its translation into Indonesian. The data collected contains words: phrases that contain cultural terms from the source language and target language. The data were analyzed using componential analysis model proposed by Katz and Fodor (1963) and Nida (1982). The following are some of the steps that were followed: (1) Select the words from the text namely meurukon text from Acehnese into Indonesian, which comprises some general components and the meaning chosen was in correspondence with the words; (2) enlist all specific semantics features referred to the cultural words based on Newmark theory in Acehnese and Indonesian using two kinds of dictionaries: Acehnese dictionary (1985) and Indonesian Dictionary (2008); (3) determine the diagnostic components that can be used for each word, then describe them one by one; and (4) describe the diagnostic components in narrative form and then take a conclusion.

\section{Results and discussion}

The total data consisted of 623 sentences. Since it is a huge number to analyze in qualitative reasearch, it focused only on cultural words that have been categorized into five by Newmark (1988). A detailed explanation on the analysis of semantics equivalence in meurukon text can be seen in the following.

The discussion and conclusion can be seen in the following table that shows the differences in equivalence between the source text and target text in each cultural category. To avoid redundancies, only the words exhibiting equivalences are shown below.

The table above shows that all the 11 terms of ecology culture in source text has semantics equivalence in target text. It means that the meaning of source text of ecology culture equivalenced with the meaning in target text.

It can be seen from the above table that six among seven $(85.7 \%$ ) material cultures can be found to have equivalence in semantic target text, while only $14.3 \%$ is unequivalent. The name of a place, however, cannot be translated into target text. If it is attempted, then it would bring about a significant shift in meaning.

It can be seen from the above table that four terms among seven $(57.1 \%)$ can be found to have lexical equivalence in target text, while two $(42.9 \%)$ are unequivalent in target text. It indicates that in social culture, the cultural categories cannot find equivalences on specific

\begin{tabular}{lllcc}
\cline { 2 - 4 } & No. & Category & Total Data & Data Analyzed \\
\cline { 2 - 5 } & 1 & Ecology - geographical and territory & 20 & 11 \\
& 2 & Material culture - food, clothes, places, transportations & 6 & 6 \\
Table 2. & 3 & Social culture - leisure and work & 10 & 7 \\
Data Classification of & 4 & Organization, customs, ideas - artistic, political and social, & 90 & 11 \\
Cultural Categories & 5 & $\quad$ and religious & 3 & 1 \\
Newmark (1988) & & Gesture and habits & 129 & 36 \\
\hline
\end{tabular}


cultural concept - the concept that can only be found in Acehnese, not in other languages. Such concepts should not be translated, because if it is done it would experience a significant meaning shift resulting in unequivalent meaning.

Of the 11 data analyzed, $9(81.82 \%)$ are found to be equivalent, while only $18.18 \%$ is unequivalent. The two unequivalent terms are untranslatable. The translator should transfer the meaning of source text to target text using equivalent translation procedures. Word "meurukon" is a cultural term that cannot find its equivalence in target text (Indonesian). It should be translated with word "meurukon."

\section{Cultural \\ Terms in \\ Meurukon \\ Texts}

\begin{tabular}{|c|c|c|c|c|}
\hline No. & Source Text & Glossary & Target Text & Level of Equivalence \\
\hline 1 & $\begin{array}{l}\text { langet and donya } \\
\text { [Sky and earth] }\end{array}$ & God's creation & $\begin{array}{l}\text { Langit [sky] } \\
\text { and dunia [world] }\end{array}$ & Equivalent \\
\hline 2 & Tanoeh Anoe & Name of place & Tanoeh Anoe & Equivalent \\
\hline 3 & nanggroe baka & Place after died & alam akhirat & Equivalent \\
\hline 4 & rhoet ngon di blang & Street and field & jalan and sawah & Equivalent \\
\hline 5 & cicem hamamah & Pigeon & Burung merpati [pigeon ] & Equivalent \\
\hline 6 & Lampoh & Garden & Kebun [garden] & Equivalent \\
\hline 7 & bungong seulanga & Acehnese flower & $\begin{array}{l}\text { bunga kenanga } \\
\text { [kenanga flower] }\end{array}$ & Equivalent \\
\hline 8 & cempala & Name of bird & murai [small bird] & Equivalent \\
\hline 9 & ramoe and rambat & $\begin{array}{l}\text { Part of Acehnese } \\
\text { traditional house }\end{array}$ & serambi dan rambat & Equivalent \\
\hline 10 & pante [beach] & Sea part & pantai [beach] & Equivalent \\
\hline 11 & pade [paddy] & Main food & padi [paddy] & Equivalent \\
\hline
\end{tabular}

Table 3.

Result of Translation of Meurukon Text in Ecology Culture

\begin{tabular}{lllll}
\hline No. & Source Text & Glossary & Target Text & Level of Equivalence \\
\hline 1 & Jalan raya & Main road & Jalanan & Unequivalent \\
& [main road] & Name of city in Banda Aceh & $\begin{array}{l}\text { [along the road] } \\
\text { Darussalam }\end{array}$ & Equivalent \\
2 & Darossalam & Capital city of Aceh province & $\begin{array}{l}\text { Banda Aceh } \\
\text { Manda }\end{array}$ & Equivalent \\
4 & Meunasah & $\begin{array}{l}\text { Place for praying of Muslim } \\
\text { villagers }\end{array}$ & Equivalent \\
5 & Makah & Holy place & Mekkah & Equivalent \\
6 & Neugara & Country & Negara & Equivalent
\end{tabular}

Table 4.

Result of Translation of Meurukon Text in Material Culture

\begin{tabular}{|c|c|c|c|c|c|}
\hline No. & Source Text & Glossary & Target Text & $\begin{array}{l}\text { Level of } \\
\text { Equivalence }\end{array}$ & \\
\hline 1 & Syehkuna & teacher meurukon & guru [teacher] & Unequivalent & \\
\hline 2 & Piasan & A show & Tontonan & Unequivalent & \\
\hline 3 & teungku & Teacherof reciting Quran & teungku & Equivalent & \\
\hline 4 & $\begin{array}{l}\text { Teungkuimum } \\
\text { meunasah }\end{array}$ & $\begin{array}{l}\text { Leader of shalat in } \\
\text { meunasah }\end{array}$ & $\begin{array}{l}\text { Tengku imam } \\
\text { meunasah }\end{array}$ & Equivalent & Table 5 \\
\hline 5 & teungku syiah & Intelectual person & ulama & Equivalent & Result of Translation \\
\hline 6 & teungku cut & Islamics teacher & guru [general teacher] & Unequivalent & of Meurukon Text in \\
\hline 7 & u'lama & Ulama & ulama & Equivalent & Social Culture \\
\hline
\end{tabular}


Proceedings of The phrase "Abu Krueng Kale" basically refers to the name of a person who is good at Islam MICoMS 2017 (ulama). In Aceh, mostly people called the name of ulama based on his place of living or village. The phrase "Abu Krueng Kale" is translated into target language also with the same phrase. The translator has done his best.

\section{8}

\section{Conclusion}

Based on the result of analysis, it was found out that in general the cultural terms in meurukon text have high equivalences with the translated text. Of the 140 data on cultural terms analyzed, 36 consisted of 11 ecology cultures, 6 on material culture, 7 on social culture, 11 on organization culture, and 1 on the culture of gestures and habit. The result of analysis of ecology cultures shows us that $100 \%$ has high equivalences with the target text. In material cultures, it was found that only $14.3 \%$ data has unequivalence with target text, and $85.7 \%$ has had great equivalences. In social cultures, $57.1 \%$ was found to be equivalent while $42.9 \%$ was not. In organization cultures (customs, activity, political, religious, and art concept), it was found that $81.82 \%$ had good equivalence while only $18.18 \%$ did not. In the last one, gestures and habit culture, $100 \%$ has good equivalence from souce text into target text.

Based on the result of analysis of data in meurukon text on semantics equivalence of cultural words, it is shown that from 623 sentences, 129 cultural words and phrases were found to be equivalent. From the data analysis, it is shown that only $16.66 \%$ of the data is not equivalent with the target text, while $83.34 \%$ of words and phrases of meurukon text are equivalent. It means that the result of translation of meurukon text has high semantics or lexical equivalences with the target text. The finding of this research also indicated that in translating the cultural text, the translator should focus not only on single word but also on context. The equivalences and the function of each word would be different if it is put in a different context.

Table 6.

Result of Translation of Meurukon Text in Organization Culture, Customs, Activity, Concept of Politics, Religious, and Art

\begin{tabular}{rllll}
\hline No. & Source Text & Glossary & Target Text & Level of Equivalence \\
\hline 1 & Meurukon & Acehnese traditional culture & $\begin{array}{l}\text { mendaras (reciting Quran) } \\
\text { khotbah (Giving lecture on }\end{array}$ & Unequivalent \\
2 & kuliah & Giving lecture on all field & $\begin{array}{l}\text { Islamic field) } \\
\end{array}$ & Selawat \\
3 & Seulaweuet & Selawat & Equivalent \\
4 & Seudati & Acehnese traditional dance & Seudati & Equivalent \\
5 & Rapai & Acehnese musical instrument & Rapai (genderang) & Equivalent \\
6 & seumayang & Prayer & shalat & Equivalent \\
7 & jeulamee & Brideprice & mahar & Equivalent \\
8 & a'lem & Pious & alim & Equivalent \\
9 & Modham & One of Islamic ideology & Mazhab & Equivalent \\
10 & Euseulam & Religion's name & Islam & Equivalent \\
11 & kaphe & Not Moslem & kafir & Equivalent \\
\hline
\end{tabular}

\section{Table 7.}

Result of Translation of Meurukon Text in Gestures and Habit Culture

\begin{tabular}{lllll}
\hline No. & Source Text & Glossary & Target Text & Level of Equivalences \\
\hline 1 & Abu Krueng Kale & Name of Acehnese ulama & Abu Krueng Kale & Equivalent \\
\hline
\end{tabular}




\section{Suggestion}

According to our research findings, it is indicated that the translation of cultural category of meurukon text depends mainly on the procedures used and the context where the terms represent lexical and phrasal meaning in the text used. Hence, it is suggested that the translator should focus more on context where the terms are used, because the accuracy in meaning in the target language can vary if it is applied in a different context.

Cultural

Terms in

Meurukon

Texts

\section{References}

Bakar, A. (1985). Kamus Aceh Indonesia. Pusat Pembinaan dan Pengembangan Bahasa Departemen Pendidikan dan Kebudayaan, Jakarta.

Baker, M. (2011). In Other Words: A Course Book on Translation (2nd ed.). Routledge, USA and Canada.

Bell, R.T. (1991). Translation and Translating: Theory and Practice. Longman, New York, NY.

Catford, J.C. (1979). A Linguistics Theory of Translation. OUP, London.

Departemen Pendidikan dan Kebudayaan. (2008). Kamus Besar Bahasa Indonesia. Balai Pustaka, Jakarta.

Lubis, S. (2010). Menerjemahkan Budaya Teks Mangupa: Sebuah teks Budaya Mandailing ke dalam Bahasa Inggris. Disertasi, Sekolah Pascasarjana Universitas Sumatera Utara, Sumatera.

Newmark, P. (1988). A Textbook of Translation. Prentice Hall International (UK), London.

Nida, E.A. (1964). Toward a Science of Translating. E.J. Brill, Leiden.

Miles, M.B, A.M. Huberman and J. Saldana. (2014). Qualitative Data Analysis: A Method Sourcebook. Third Edition. Sage Publications, Inc.

Syafruddin, S. (2017). Teks Meurukon dan Terjemahannya. Bayu, Lhokseumawe: SEFA Bumi Persada.

Seong, G.A. (2012). Bahasa Cina Bahasa Melayu: Kebolehterjemahan Budaya. Universitas Sains Malaysia Press, Pulau Pinang, Malaysia.

Usman, A.R. (2009). Budaya Aceh. Dinas Kebudayaan dan Pariwisata Aceh, Pemerintah Aceh.

\section{Corresponding author}

Nurlaila can be contacted at nurlaila_daud@ymail.com 